Communications Vol. 2 No. 2 Juli 2020

DOI:https://doi.org/10.21009/Communications.2.2.5

\title{
Generasi Digital Natives dalam Praktik Konsumsi Berita di Lingkungan \\ Digital
}

\author{
*Devie Rahmawati \\ Giri Lumakto \\ Deni Danial Kesa \\ Universitas Indonesia \\ *email: devie.r@ui.ac.id
}

\begin{abstract}
Dominant interaction among citizens in the digital world still poses the generational divide. Though the Indonesian population data showed 268 million people, yet there were 355 million smartphone (133\%). Whereas $91 \%$ of these numbers are accessed through smartphones, yet the majority of digital exchanges comes from digital natives. Digital native (17-34 years old) are the generation born as the technology flourishes. While the digital immigrants (45-64 years old) was born before technology developed rapidly. This research implemented qualitative approach. The data collection method used was two interviews using FGD with 55 respondents. The interview implemented the least-structured script. The data analysis was in the form of descriptive analysis. The research had found misinterpretation of digital competence, particularly on hoax consumption. Compared to the digital immigrants in news consumption, digital natives exhibited a schemata gap in inferring digital information. Both generations, though, demonstrated emotional drive in perceiving hoax. The digital natives are yet not able to shift any social change or reduce digital divide. A patron-client was apparently instigating hoax distribution by the digital natives.
\end{abstract}

Keywords: Digital Natives, Digital Divide, Misinformation

\begin{abstract}
ABSTRAK
Dominasi interaksi warga di dunia digital masih menyisakan ketidaksetaraan antar generasi. Walau data menunjukkan dari 268 juta penduduk Indonesia, terdapat 355 juta pengguna seluler (133\%). Dimana 91\% mengakses informasi melalui ponsel, mayoritas interaksi digital ini berasal digital native. Digital natives (17-34 tahun) adalah generasi yang lahir berdampingan dengan perkembangan teknologi. Sedang digital immigrants (45-65 tahun) lahir sebelum teknologi digital berkembang pesat. Penelitian ini menggunakan pendekatan kualitatif. Metode pengumpulan data menggunakan teknik dua kali wawancara dengan FGD dengan 55 orang responden. Ke 55 responden berasal dari digital native (20) dan digital immigrants (35). Teknik wawancara menggunakan teknik tidak terstruktur. Dengan analisis data bersifat deskriptif. Penelitian ini menemukan adanya misinterpretasi kompetensi digital, terutama dalam konsumsi informasi hoaks. Dibandingkan dengan generasi digital immigrant dalam mengkonsumsi berita, digital natives menunjukkan ketimpangan schemata dalam mengenali informasi digital. Kedua generasi masih mudah terprovokasi dengan kandungan emosional hoaks. Terjadi kendala untuk digital
\end{abstract}


native merubah kondisi sosial atas persebaran berita hoaks (digital divide). Pola patronclient menjadi salah satu penyebab hoaks menjadi informasi yang dipercaya juga oleh digital natives.

Kata kunci: Digital Natives, Kesenjangan Digital, Misinformasi

\section{A. PENDAHULUAN}

Industri sektor komunikasi terus berubah mengikuti perkembangan jasa komunikasi. Dengan tetap mengadaptasi teknologi yang menjadi bagian integral manusia modern seperti perangkat mobile. Dengan begitu, perangkat ini memungkinkan mereka kepada jasa dan informasi tanpa batas (Gkioulous, dkk., 2017; Shrivastava, 2017). Kemajuan teknologi ini juga mengakibatkan ketergantungan kepada perangkat untuk menghubungkan dengan sosial media, manajemen finansial dan jadwal dengan konektivitas tiada henti (Hofer, 2018). Kemajuan teknologi ini pun mendisrupsi perilaku individu dan secara signifikan mengubah cara orang berperilaku, berpikir, dan cara hidup (Shrivastava, 2017). Semua hal ini mungkin terjadi karena teknologi mobile memfasilitasi individu tergantung kepada Internet untuk bekerja dan beraktivitas sehari-hari (Po-Hong Shih, et al 2018). Dengan jumlah pengguna internet melebihi 4,39 miliar secara global di tahun 2019. Ditambah pengguna sosial media juga tumbuh menjadi 3,48 miliar. Bertambah 288 juta pengguna baru dibandingkan tahun 2018 (We Are Social, 2019). Internet menjadi bagian dari peradaban 7,6 miliar lebih populasi secara global. Dengan kata lain sudah hampir $45 \%$ penduduk dunia kini memiliki akses, perangkat, dan kemampuan finansial untuk terkoneksi dengan Internet.

Penduduk Indonesia juga tidak terlepas dari trend global ini. Saat ini, ada 355 juta orang Indonesia memiliki perangkat digital. Sehingga Jumlah perangkat digital melebihi populasi Indonesia (268 juta jiwa). Dengan 91\% dari pengguna Internet mengaksesnya melalui mobile device. Akan tetapi, cepatnya pertumbuhan perangkat telekomunikasi dan teknologi, tidak bisa dirangkul oleh generasi yang lebih senior. Generasi yang lebih senior ini mungkin tidak begitu tertarik dengan teknologi tersebut 
dibandingkan dengan generasi yang lebih muda. Mereka akan menghadapi kendala dalam mengadaptasi pada perangkat dan kecakapan baru (Po-Hong Shih, dkk., 2018). Hal ini terbukti dari data We Are Social (2019), dimana 59\% pengguna sosial media berasal dari usia 17-34 tahun. Dengan populasi senior berusia 45-65 tahun hanya 20\% dari total 3,48 miliar. Sehingga para peneliti telah membagi jenis pengguna Internet secara menjadi dua yaitu: digital immigrants dan digital natives. 
Digital immigrants adalah orang-orang yang lahir sebelum tahun 1980. Mereka memiliki pengalaman berinteraksi dengan komputer melalui komunikasi langsung. Mereka juga tumbuh bersama dalam era tatap muka yang mengharuskan tugas offline dan berbasis kertas. Generasi ini juga terbiasa menggunakan metode konvensional dalam beradaptasi dengan teknologi baru dibandingkan dari yang dilakukan generasi digital native. Generasi digital native adalah generasi yang lahir setelah tahun 1980. Mereka tumbuh dalam era yang memungkinkan sumber pembelajaran menjadi berlimpah. Dimana lanskap teknologi dijejali dengan komputer digital dan akses Internet tanpa batas, video gim, smartphone, pemutar lagu digital, video perekam, telepon selular, televisi interaktif, asisten digital pribadi, dan perangkat digital lain.

Generasi native ini memiliki sifat integratif dalam teknologi digital. Hal ini memungkinkan mereka lebih banyak berinteraksi sosial di sosial media daripada generasi sebelumnya. Generasi ini memiliki cara mereka sendiri terlibat dengan lingkungan fisik mereka. Mereka handal dalam penggunaan perangkat teknologi devices beserta fiturnya seperti email, instant messaging, Internet, dan SMS (Chaves, dkk., 2016; Zarenejad, 2018; Dahl, dkk., 2018; Zimerman, 2012; Lazorko, 2015; Furini, 2014; Stockham, 2016; Purnell, 2017; Spangler, 2015; Wang, dkk., 2013; Núñez-Gómez dkk., 2012; Tufts, 2010; Young, 2012; Kesterson 2015; Bates, 2013; Islam Manik, D.2015). Namun penting untuk digarisbawahi karakter para digital natives yang menjadi generasi awal yang mengenal teknologi dan layanannya seperti kebiasaan, perilaku, dan gaya hidup mereka. Aspek-aspek ini adalah indikator kontemporer yang baik. Sejauh dari kajian literatur yang ada, tidak ada studi terdahulu yang membahas bagaimana generasi ini mengkonsumsi media, terutama menyoal berita bohong (hoaks). Pengaruh sosial dengan lebih spesifik norma sosial dalam beberapa studi menunjukkan pengaruh perilaku yang pro-sosial dan juga pengambil resiko. Beberapa studi menemukan pengaruh sosial memiliki dampak yang radikal pada adopsi media, integrasi sosial, dan adopsi teknologi. 


\section{B. TINJAUAN PUSTAKA}

Menurut Maslow (1943), kompetensi lahir dari kepuasan terhadap pencapaian pribadi yang membangkitkan rasa percaya diri, patut dihargai, kecakapan, dan kemapanan bertindak dari seorang individu. Kesemuanya menjadi sebuah kebermanfaatan bagi sesama. Sehingga kompetensi pun mendorong self- actualization atau saat individu terus melakukan aktivitas atau profesi yang ia mampu lakukan. Seorang musisi akan terus mengkomposisi dan menciptakan karya seni berupa lagu dan aransemen. Seorang pelukis akan terus berkarya melahirkan karya lukis yang bagus. Dan masih banyak lagi bidang atau aktivitas yang memerlukan kompetensi seseorang agar menjadi lebih baik.

Menurut Heylighen (1992), berdasarkan pengembangan konsep motivasi dari Maslow, ada 3 komponen penting sebuah kompetensi yang harus dipenuhi yaitu sebagai berikut:

1. Kompetensi mensyaratkan adanya entitas yang dibutuhkan, atau sering disebut sebagai kompetensi material.

2. Kompetensi mensyaratkan pengembangan dari entitas yang sudah ada, atau membutuhkan pengetahuan dan kreatifitas.

3. Kompetensi juga mensyaratkan penilaian subjektif individu yang memiliki sebuah kompetensi.

Teori kompetensi menyatakan bahwa individu yang memiliki kompetensi rendah cenderung merasakan over-confidence atau percaya diri berlebihan. Terutama dengan pengetahuan dan kecakapan yang mereka miliki. Sementara itu, mereka tidak menyadari kekurangan dalam kapabilitasnya. Mereka menunjukkan tingkat optimisme yang lebih tinggi daripada pengetahuan dan kecakapan yang dimiliki. Kelemahan dalam menilai kemampuan pribadi mendorong individu tersebut akan mengabaikan penilaian pada informasi dan berita. Percaya diri berlebihan 
terkait dengan ketidakmampuan membuat keputusan efektif pada informasi dan sumber berita. Kurangnya pemahaman tentang sirkulasi informasi, ditambah dengan rasa percaya yang tinggi, dapat mendorong generasi digital native gagal memahami batasan kemampuan mereka (Bates, 2013). Sebagai sebuah konsep, kompetensi digital mensyaratkan penelusuran lebih jauh untuk mengklarifikasi karakter dari beberapa generasi, khususnya yang terkait dengan perilaku konsumsi media. Terlepas dari akses yang bertambah bagi kalangan digital native untuk mendapat beragam berita dan informasi, membekali mereka dengan kemampuan untuk menelusuri lebih dalam setiap informasi, diperlukan agar mereka mendapat sumber informasi yang kredibel.

Schemata atau schema menurut Bartlett (dalam McVee dkk., 2005) adalah sebuah fenomena yang lebih dari yang kita pikirkan dan menjadi dasar seorang individu untuk mengetahui pola yang merentang ke dalam dunia sosial dan kultural. Sebuah persepsi didasarkan pada asumsi bahwa realitas tergantung pada pemahaman individu. Sedang bagi Piaget (dalam McVEe dkk., 2005) schemata menunjukkan perkembangan yang merupakan simbol dari dialektika individu untuk mengasimilasi pengalaman baru dengan schema yang telah ada sebelumnya yang berasal dari pengalamannya. Lebih detail, Rumelhart (dalam McVee, dkk. 2005) menjabarkan schemata memiliki lima variabel yaitu: 1) Schema dapat dilekatkan dengan schema lain, 2) Schema merepresentasikan pengetahuan dari berbagai level abstraksi, 3) Schema menunjukkan pengetahuan dan bukan sekadar definisi, 4) Schema merupakan sebuah proses yang aktif, 5) Schema merupakan perangkat pemahaman dengan tujuan untuk mengevaluasi.

McVee dkk (2005) menambahkan bahwa konsep schema berasal dari upaya untuk memahami dan mendalami proses berpikir seorang individu yang begitu rumit terkait erat dengan kehidupannya secara kultural. Pengetahuan individu terkait erat dengn pengalaman yang dialamai secara kultural. Lebih jauh dalam perkembangan individu, teori schema menjadi faktor dominan dalam pengembangan kecakapan membaca komprehensif (reading comprehension). Teori schema menjadi bagian dari reading comprehension arena mendorong proses memahami dengan pengetahuan 
Communications Vol. 2 No. 2 Juli 2020

DOI:https://doi.org/10.21009/Communications.2.2.5

terdahulu dan kemudian memberikan makna. 
Konsep schemata menyatakan bahwa sebuah schema individu, berasal dari latar belakang pengetahuan dan pengalaman hasil interaksi terdahulu. Schema digunakan untuk memahami bagaimana seseorang menjalani kehidupannya di dunia, salah satunya perilaku konsumsi informasi dan berita. Perilaku ini berbasis kemampuan literasi digital dan schema yang telah dialami seseorang. Jika schema yang sudah ada mampu memahami informasi dan berita dengan benar, konsumen tersebut dapat mencerna informasi tersebut dengan proporsional. Jika schema yang telah ada tidak mampu memahami informasi dan berita, konsumen pun mengalami kebingungan dan harus dengan segera memfungsikan schemata untuk mencerna informasi dan berita (Kesterson, 2015).

Rosenblatt (1988) mendefinisikan transaksional sebagai kaitan aktivitas manusia dan bermacam interelasinya. Sedang individu menjadi bagian dari transaksi elemen sosial, kultural, dan alamiah yang telah ada. Mode berpikir transaksional telah lama terutama terkait dengan ranah ekologi. Dalam bahasa individu pun bertransaksi dengan kosakata yang berkaitan erat dengan alam sekitar. Oleh sebab itu, Rosenblatt menegaskan bahwa kata-kata tidak terisolasi fungsinya. Kata-kata akan selalu terkait dengan tindakan verbal, personal, dan konteks sosialnya. Dalam hal ini, teks yang berisi kosakata pun mengacu pada konteks yang lebih luas. Membaca pun menjadi sebuah proses transaksional. Dan dalam prosesnya, ada 2 jenis yang diketahui yaitu membaca efferent dan aesthetic.

Proses membaca dengan pola efferent terjadi saat seorang akan langsung membaca kata yang ada di hadapannya. Dengan kemudaia, mengkonstruksi tindakan lebih lanjut. Contoh membaca dengan proses efferent adalah membaca koran, buku teks, atau undang-undang. Dalam proses efferent fokusnya adalah mengabstraksi dan menganalisis struktur gagasan, informasi, arah, dan kesimpulan. Sedang proses membaca berpola aesthetic berfokus pada situasi saat membaca seperti sensasi, citra, perasaan, dan gagasan yang menjadi residu psikologis dari kata-kata dan konsep efferent-nya. Membaca aesthetic pun terkait transaksi dengan teks yang bersifat 
Communications Vol. 2 No. 2 Juli 2020

DOI:https://doi.org/10.21009/Communications.2.2.5

kesusastraan seperti mantra, puisi, drama, dan monolog (Rosenblatt, 1988). 
Konsep membaca transaksional menyatakan bahwa konsumen berinteraksi dengan sebuah teks dengan pengetahuan historis yang dimiliki, untuk memperoleh pemahaman, konsep, dan nilai dari tiap "transaksi” dengan teks. Konsumen sebuah teks mempersiapkan schemata terdahulu mereka untuk setiap interaksi dengan teks. Mereka juga mengembangkan kecakapan personal dari latar belakang historis mereka sendiri. Mengkonsumsi informasi dan berita dengan konsep ini berarti terjadi dialog antara schemata dan teks, dalam mekanisme transaksi. Proses dialog ini memiliki dua probabilitas dampak. Pertama, adalah transaksi efferent, yang berfokus pada pemahaman kognitif yang membantu pembaca mengingat dan merasakan. Dampak yang kedua adalah transaksi aesthetic, yang mengedepankan efek emosional saat mengkonsumsi sebuah informasi atau berita. Transaksi yang kedua bergantung pada perasaan personal dan latar belakang individu (Kesterson, 2015).

Berita bohong atau yang kini dikenal dengan sebutan hoaks sudah menjadi pandemi informasi secara global. Produksi dan distribusi berita bohong semakin masif, sistematis, dan terstruktur. Klasifikasi hoaks menurut Wardle dan Derakhshan (2018, dalam Ireton dan Posetti 2018) yang dibagi menjadi dua: misinformasi dan disinformasi. Misinformasi adalah informasi yang salah dengan penerima pesan tersebut tidak mengetahui kepalsuan informasi tersebut. Disinformation adalah informasi palsu dengan pelaku penyebarnya paham secara sadar informasi tersebut palsu. Tujuannya tidak lain adalah secara aktif menyesatkan publik. Edson dkk., (2018) lebih jauh membuat tipologi hoaks menjadi enam; satire, parodi, fabrikasi, manipulasi, iklan dan propaganda.

Beberapa penyebab signifikan hoaks bisa begitu cepat menyebar ditelaah oleh Posetti (2018, dalam Ireton dan Posetti). Seperti faktor lunturnya kepercayaan kepada jurnalisme dan media arus utama. Faktor lain adalah keinginan user pada berita 'ondemand', dengan perangkat digital secara real-time melalui sosial media. Hal ini mengakibatkan tekanan jurnalis profesional dalam siklus berita 
tiada henti. Dan faktor yang juga tidak kalah penting adalah kemunculan propaganda sistematis dan amplifikasi ketidakjujuran. Peran platform digital sebagai media distribusi informasi juga dianggap lemah dalam menangkal hoaks yang viral dan beredar cepat.

Kesenjangan digital, atau digital divide merupakan konsep yang telah lama ada. Pada awal mulanya, konsep kesenjangan digital ini berfokus pada kemampuan memiliki (ekonomi) dan mengoperasikan perangkat digital (komputer) dan akses (Internet). Namun, konsep ini telah berkembang menjadi beberapa aspek yang lebih komprehensif. Warschauer (2004) merangkumnya ke dalam lima variabel kesenjangan digital yaitu: teknis (ketimpangan bandwidth), otonomi (login dari rumah atau tempat lain), kecakapan (cara memperoleh informasi), dukungan sosial (ketersediaan orang di sekitar yang melek teknologi), dan tujuan (berselancar di Internet untuk bisnis, hiburan, dsb). Sedang Cullen (2001) mendefinisikan kesenjangan digital atau digital divide sebagai ketergunaan teknologi TIK pada level yang lebih tinggi. Level ini mengacu kepada interaksi dan transfer informasi digital dengan format digital yang lebih banyak. Walau proses ini akan tergantikan satu dekade ke depan. Manfaat dan akses dari dunia informasi digital ini menjadi indikasi semua warga negara mendapatkan manfaatnya seperti halnya pada negara-negara maju.

Cullen (2001) mengutip laporan media survei Gartner Group menemukan adanya kesenjangan atas kecakapan komputer (computing skill) pada anak sekolah dengan dibandingkan orang Afrika-Amerika, orang berusia lanjut, dan masyarakat di daerah rural atau desa. Hambatan atas kecakapan digital dapat berupa: a). Terbatasnya akses fisik berupa infrastruktur telekomunikasi, b). Kurangnya kecakapan (skill) ICT dan pendukungnya, c). Rumitnya persepsi terhadap orang 'melek digital', d). Tidak relevannya konten dari informasi digital.

Sebuah hubungan patron-client membutuhkan berlapis fase dan banyak aktor di dalamnya, bukan sekadar hubungan sementara (Wolf, 1966). Secara timbal balik, sang patron akan memberikan sumbangsh ekonomi maupun perlindungan tanpa 
memerlukan balas jasa. Baik itu hal-hal yang legal maupun ilegal. Sedang klien secara sukarela akan menyediakan aset berupa energi, pikiran, dan waktunya. Atau secara singkat, memberikan loyalitasnya. Penyebab dari hubungan patron-client ini lebih jauh ditelaah Eisenstadt dan Roniger (1980) sebagai sebuah bentuk hubungan berdasar penghargaan (honor) dan spiritual. Sehingga, pola hubungan macam ini menimbulkan sebuah konstruksi sumber daya, pertukaran informasi, dan kekuasaan yang cukup rumit dan kompleks dalam masyarakat. Lebih lanjut Eisenstadt dan Roniger (1980) menjabarkan karakteristik dari hubungan patron-client sebagai berikut: a). Bersifat khusus atau spesial (particularistics) dan menyatu, b). Terjadi pertukaran terus menerus dari instrumen ekonomi dan politik (dukungan, loyalitas, surat suara dan perlindungan), c). Pertukaran yang terjadi bisa dalam bentuk paket atau terpisah, d). Adanya kontrak tidak tertulis atas hak dan kewajiban, walau ambivalen, aspek solidaritas cukup kental, e). Hubungan yang ada dan dibuat tidak berdasar asas hukum atau kontrak, walau mengikat, hubungan yang terjadi bersifat kerelawanan (voluntary), f). Hubungan ini didasarkan pada ketimpangan sumber daya dan kekuasaan.

\section{METODE PENELITIAN}

Penelitian ini mengimplementasikan pendekatan kualitatif terhadap 55 narasumber dari tiga kota di Indonesia Depok, Bekasi dan Jakarta. Para narasumber ini adalah para partisipan dari program Klinik Digital Vokasi Humas Universitas Indonesia, yang berlangsung selama sepuluh bulan dari Februari hingga Oktober 2019. Tujuan dari penelitian kualitatif ini adalah mengungkap persepsi dan pengalaman para digital natives yang menggunakan teknologi digital.

Penelitian ini dilakukan dengan mengamati aktivitas sehari-hari dalam mengkonsumsi informasi dan berita dari Internet serta bagaimana para digital 
native menyebarkan informasi kepada sesama. Karena dalam penelitian kualitatif, tujuan utamanya adalah memahami perspektif partisipan, sehingga diperoleh pengetahuan dan pemahaman tentang dunia sosial dari perspektif pelaku (Rahmawati dkk., 2018, 2019).

Proses memperoleh informasi dilakukan untuk mendapatkan cakupan informasi yang lebih luas, yaitu dengan melakukan wawancara mendalam. Proses interview dilakukan dua kali untuk tiap narasumber. Hasil dari wawancara ditelaah dan disarikan ke dalam elaborasi deskriptif. Untuk kemudian transkrip FGD atau wawancara yang tepat dan relevan dengan teori dijabarkan lebih lanjut.

\section{HASIL PENELITIAN}

Hasil dari sepuluh bulan penelitian kualitatif adalah lima temuan yang terkait perspektif dan pengalaman dari para narasumber terkait konsumsi media, terutama terkait hoaks dan berita, yaitu: 1) Para digital natives mengalami misinterpretasi kompetensi digital dengan pengalaman atau kelihaian mereka menggunakan teknologi dalam konteks literasi media untuk memerangi distribusi berita palsu, 2). Schemata para digital native berada dalam kondisi disequilibrium atau timpang. Hal ini karena minimnya schemata yang dimiliki untuk mengasimilasi teks digital, 3). Perilaku konsumsi informasi dan berita digital memiliki dampak emosional kepada para digital native, 4). Kendala para digital native menjadi agen perubahan untuk lingkungan mereka, seperti melawan konsumsi informasi dan berita hoaks. Walau para digital natives dan immigrant menggunakan platform yang sama untuk mendapatkan berita. Ada perspektif yang berbeda dalam memahaminya, 5). Cara digital natives beradaptasi dan memahami informasi dan berita menggunakan struktur patron-client digital.

\section{Misinterpretasi Kompetensi Digital}

Kompetensi digital mencakup kompetensi literasi, yang merupakan kompetensi membaca dan menulis, sebagai kecakapan strategis di era digital (Kesterson, 2015). 
Banyak dari kecakapan ini dikembangkan selama pendidikan formal. Hasil dari perolehan kompetensi membaca dan menulis intensif dilakukan di berbagai aspek kurikulum. Penelitian ini menemukan bahwa kemampuan membaca tidak mempengaruhi kompetensi di area lain karena adanya capaian yang rendah dalam memahami sebuah teks. Lebih jauh, pemahaman rendah ini terkait dengan konten dan kanal komunikasi yang mereka gunakan.

Para digital native cenderung merasa terlalu percaya diri dengan level kompetensi literasi mereka. Mereka berada dalam kondisi dimana mereka tidak menyadari keterbatasan mereka sendiri dalam memahami informasi dan berita hoaks. Akan tetapi rasa percaya diri mereka cukup tinggi jika dibandingkan dengan individu yang lebih terlatih. Lebih lanjut, mereka merasa sangat yakin dapat mengidentifikasi tingkat literasi orang lain, terutama para digital immigrants.

Dari pengamatan mengenali aktivitas digital mereka, ditemukan juga bahwa sebenarnya para digital natives sangat terbatas dalam hal memahami informasi mana yang dianggap kredibel. Perbedaan mereka dengan para digital immigrant hanya pada tema dari informasi. Ketika mereka menyampaikan pendapat bahwa mereka sebenarnya merasa bahwa orang tua mereka memiliki kapasitas yang rendah, mereka pun sebenarnya ketika dikonfirmasi tentang berbagai informasi selama wawancara, juga memiliki kecakapan yang lemah untuk membedakan 
mana berita yang dapat dipercaya atau tidak. Salah satu temuan menarik ialah para digital natives ini menjadikan media sosial seperti facebook dan line misalnya sebagai sumber berita. Mereka tidak satupun yang menyebutkan sumber-sumber berita dari media online yang kredibilitasnya tinggi. Mereka menyangsikan informasi yang dimiliki orang tua mereka, namun dengan menggunakan juga informasi dari media sosial.

Para digital natives juga memerlukan bimbingan baik dari rekan mereka atau orang dewasa agar mereka tetap sadar akan informasi dan berita yang tidak kredibel. Di sisi digital immigrant, mereka mengalami kesenjangan kemampuan. Dalam konteks ini, para orang tua merasa mampu mencari informasi. Namun tidak sama dengan kemampuan anak atau narasumber. Kesenjangan lain yang dihadapi generasi immigrants adalah dukungan sosial. Walaupun anaknya yang melek dunia digital mau membantu. Namun ada keengganan orang tua untuk dibantu. Hal ini terjadi karena orang tua merasa kurang terbuka, atau tidak suka jika dibantu anaknya yang lebih mahir menggunakan perangkat digital.

\section{Schemata para Digital Native}

Para narasumber terkadang berada dalam kondisi seimbang dan timpang pada saat mengakses dan memahami sebuah informasi dan berita. Saat mereka tidak dapat memahami informasi dan berita dengan benar lalu mengkonsumsi hoaks, mereka dalam kondisi timpang. Namun kondisi ini tidak pernah berlangsung lama dibanding dengan generasi yang lain. Hal ini karena para narasumber telah memiliki schemata dasar yang berguna untuk menginterpretasi kebaruan informasi dan berita. Berikut ini, salah satu pernyataan dari informan penelitian ini: "Saat saya menerima sebuah berita tentang kematian seorang selebriti, dulu saya mudah percaya. Namun seiring waktu, saya selalu mencoba untuk mengeceknya dengan sumber lain. Beberapa informasi awal benar, tetapi kebanyakan adalah hoaks. Saya belajar dari pengalaman saya."

Lanskap literasi digital telah bergeser dari membaca dan menulis secara konvensional, saat ini perilaku para narasumber telah mentransfernya dari teks cetak dengan 
perangkat asisten digital menjadi teks digital yang lebih interaktif. Praktik seperti ini memungkinkan para digital natives menjadikan dan mengintegrasi semua media nonlinear, guna menelisik informasi dan berita yang mereka dapat. Sehingga saat mereka "tersesat", schemata mereka akan menjadi penerang menuju kebenaran. Ketimpangan pengetahuan mereka dalam mengkonsumsi sebuah informasi hoaks misalnya, dapat dengan cepat dikoreksi ketika ekosistem digital memang memungkinkan berbagai informasi, sanggahan, koreksi dan berbagai informasi saling berkeliaran. Ini menjadi berkah bagi digital native untuk terus memiliki informasi terkini, yang dengan cepat membuat mereka menyusun ulang informasi bahkan kepercayaan mereka terhadap sebuah berita. Sehingga, ada kesenjangan digital berupa skills dalam pencarian informasi terlihat disini.

Generasi immigrants nampak kurang cekatan sekaligus enggan menelusur informasi. Bukan karena tidak mampu. Tetapi anaknya merasa lebih mahir dalam mencari informasi. Digital natives memiliki schemata teknologi yang lebih unggul daripada para orang tuanya. Sehingga informasi yang didapat dan diolah bisa ditelusuri lebih jauh jika diperlukan. Tidak seperti orang tua mereka sebagai digital immigrants yang cenderung menerima informasi begitu saja.

\section{Perilaku "Emosional"}

Saat digital native ini berinteraksi dengan teks digital, mereka membawa serta pengetahuan historis guna memahami polanya, menelaah, dan memaknai setiap "transaksi" dengan teks. Para narasumber menggunakan kumpulan schemata untuk memahami fenomena. Namun banyak dari mereka menggunakan latar schemata "emosional" untuk memaknai informasi dan berita format digital. Hal ini mengapa, walaupun tumbuh dalam ekosistem digital, serta memiliki status warga digital, insting dasar emosional merekalah yang mengarahkan konsumsi hoaks. Reaksi emosional mereka menggantikan rasionalitas untuk memahami informasi dan berita.

Reaksi emosional ini ada dalam bermacam tema. Mayoritas isu yang dapat mempengaruhi para narasumber adalah yang menyangkut gaya hidup mereka seharihari seperti arus lalu lintas; kebutuhan studi; tempat makan; fashion; perangkat IT. Saat 
menghadapi isu-isu seperti ini, kebanyakan narasumber berpotensi masuk ke dalam perangkap hoaks. Karena isu-isu merupakan isu keseharian, yang memang melekat dalam kehidupan mereka. Mereka cenderung menerimanya begitu saja (taken for granted). Mereka dengan sadar mengabaikan upaya untuk melakukan verifikasi terhadap informasi yang ada, karena faktor kebutuhan, yang mendorong mereka untuk cepat mengkonsumsi kebutuhan tersebut di dunia offline. Memang informasi informasi tersebut memiliki tingkat "bahaya" yang relatif rendah dibandingkan dengan tema keagamaan yang berpotensi mendorong pembacanya melakukan tindakan kekerasan akibat pemahaman yang emosional. Namun, hal ini menjadikan "tradisi" verifikasi semakin rendah di kalangan digital natives ini.

\section{Kendala Sosial dan Kultural}

Sebagai generasi yang lahir di peradaban digital, kaum natives ini menganggap dunia digital adalah perpanjangan kehidupan domestik dan publik mereka. Mereka memiliki identitas permanen di Internet dimana mereka mengkonsumsi dan memproduksi konten di waktu bersamaan. Bagi mereka, kehidupan di Internet adalah kehidupan yang nyata halnya dengan kehidupan offline mereka. Mereka memahami hal ini dan selalu berusaha untuk meng-update pengetahuan, kecakapan dan sikap mereka kepada kehidupan dan produk digital. Sehingga mereka merasa memiliki kewajiban moral menjadi ambassador dunia digital di dalam kehidupan nyata mereka. Terkait persebaran informasi hoaks, mereka mengakui telah banyak berbagi pengetahuan dan keterampilan kepada saudara dan keluarga mereka agar terhindar tipu daya hoaks. Namun hal tersebut pelik. Generasi lain sulit diberi pengertian. Sebagaimana generasi orang tua mereka yang asing dengan fitur interaktif digital dan tidak dibesarkan dekat dengan akses digital sebagai sumber ilmu pengetahuan selama masa pendidikan mereka.

Generasi immigrant selalu merasa pesimis terhadap kemampuan dan kemauan para natives untuk memahami sebuah fenomena dengan hanya mengkonsumsi teks digital. 
Kendala kultural ini membuat para narasumber menjadi skeptis kepada para digital immigrants tentang cara menangkal hoaks. Setiap langkah yang generasi native lakukan, para immigrant menganggapnya sebagai sebuah penghinaan. Para immigrant kerap kali menggunakan narasi religius untuk menekan kelompok natives untuk mengkonsumsi dan mempercayai berita yang disebarkan oleh para immigrants. Ketika natives dipojokkan dengan narasi budaya religius tersebut, maka mereka akan menunjukkan konformitas. Situasi ini tidak hanya melemahkan mental para natives, namun jelas mengikis budaya kritis yang sebenarnya menjadi bagian yang tidak terpisahkan dari generasi natives ini. Mengingat ekosistem digital selalu memperbarui berbagai informasi tanpa diminta dan bahkan disadari.

Penelitian ini juga mendapati para narasumber memiliki sikap percaya diri berlebihan tentang kemampuan mereka sendiri dalam menggunakan teknologi. Dari proses observasi, penelitian ini menemukan bahwa keberlimpahan sumber pengetahuan, tidak dimanfaatkan oleh para generasi native. Mereka bergantung sekali kepada mesin peramban sebagai sumber informasi. Kemalasan mereka untuk memperluas cakupan sumber penelusuran menjadi sebuah paradoks dibandingkan dengan kecepatan mereka mencari informasi. Kerentanan kepada konteks, kompleksitas dan kredibilitas sumber menjadi problema saat ini dan di masa depan. Hal ini terjadi karena dalam lanskap digital, generasi native bergantung pada patron atau tauladan digital guna mendapat informasi akurat, relevan dan otoritatif yang mereka cari. Mereka biasanya mencontoh pada selebritis digital atau individu populer untuk proses mengolah, mengadaptasi dan mengevaluasi informasi dan berita yang mereka dapatkan.

Para narasumber bergantung pada para patron mereka di dunia digital untuk mendapatkan kebenaran jika mereka mendapatkan information dan berita yang mencurigakan. Mereka sangat cekatan dalam memahami perangkat teknologi, tetapi bukan berarti mereka memiliki kapasitas untuk menggunakan mesin peramban dengan baik ataupun memahami sumber informasi mana yang terbaik. Jurang antara apa yang para narasumber ketahui tentang penelusuran informasi dan berita research dengan apa yang sebenarnya para digital native sebenarnya pahami, disesaki dengan informasi dan berita dari patron mereka. Dari observasi ini bisa ditemukan 
temuan ironis. Saat para digital native merasa memiliki sumber pengetahuan dalam genggamannya. Mereka masih memerlukan dukungan sosial. Dalam konsep kesenjangan digital dari Warschauer (2004), hal ini mungkin bertentangan dengan variabel dukungan sosial. Dimana orang yang tidak mahir dalam teknologi mencari bantuan mereka yang mahir. Namun, patron digital yang dijadikan acuan atau referensi para native membuktikan sebaliknya. Mereka masih dan perlu dukungan sosial. Dalam hal ini berinteraksi secara digital melalui platform sosial media.

\section{E. KESIMPULAN}

Generasi digital native nampaknya mengalami ketimpangan dalam pemrosesan informasi dan berita, terutama hoaks. Jika terkait figur publik yang mereka idolakan, hoaks yang disebarkan tokoh tersebut bisa saja langsung diterima. Hal ini serupa dengan para digital immigrants yang begitu saja membenarkan sebuah informasi atau berita di sosial media. Kompetensi digital yang dimiliki digital native tidak begitu saja terkait dengan kecerdasan mengolah informasi dan berita. Hal ini relevan dengan konsep kompetensi, konsep schemata, dan membaca transaksional di atas. Ketergantungan generasi native pada mesin pencari malah menjadikan mereka rentan berpikir kritis. Mengandalkan mesin peramban baik untuk membuka cakrawala. Namun tidak dengan memahami secara kritis dan solutif suatu konteks dan isu. Pola berpikir kritis, tidak tergesa, dan bijak mungkin dimiliki para digital immigrant, dan bukan generasi native.

Data yang telah terkumpul dan dianalisis dari penelitian ini menyiratkan bahwa para digital native memiliki pola yang berbeda dalam hal mengkonsumsi media. Mereka memiliki beberapa karakteristik yang membuat mereka tidak imun atau rentan dari penetrasi hoaks. Guna mencegah hal tersebut, masyarakat perlu mengadaptasi inklusi digital yang memiliki tiga dimensi yaitu: akses, daya beli, dan kecakapan digital. Akses meliputi akses Internet: frekuensi, lokasi, dan jumlah access points; Teknologi Internet: komputer, ponsel, mobile broadband, dan fixed broadband; Penambahan Internet Data: mobile dan fixed internet. Daya beli meliputi Pengeluaran Relatif: jumlah income 
rumah tangga yang habis untuk akses Internet; Nilai Pengeluaran: jumlah total pengeluaran untuk kuota Internet data per Rupiah anggaran. Kecakapan Digital: Sikap yang meliputi, hakikat dari kontrol, antusiasme, pembelajaran, dan percaya diri; Skill Dasar, yang meliputi kecakapan mobile phone, perbankan, berbelanja, komunitas, dan informasi; Aktivitas meliputi, mengakses konten, komunikasi, transaksi, niaga, media, dan informasi (Suwana, 2019).

Generasi digital native memang tumbuh dan hidup bersama teknologi. Namun bukan berarti akses prestisius ini memberdayakan mereka untuk berpikir kritis. Mereka masih merasa tidak percaya diri saat menemui informasi atau berita yang salah atau hoaks. Oleh sebab itu, perlu ditekankan pendidikan literasi media. Sekolah berfokus banyak pada pengembangan kognisi, tidak menyentuh literasi media. Dalam konteks verifikasi hoaks, pembelajaran cek fakta bisa menjadi solusi. Lebih lanjut, generasi digital native juga perlu memahami konsep digital citizen. Konsep ini memiliki telah diimplementasi di Australia dengan 4R yaitu: Respect, Resilience, Responsibility, dan Reasoning (Digital Citizenship.nsw.au, 2019). Respect berarti menghormati sesama di dunia maya. Resilience berarti individu yang tidak rentan terhadap hal negatif di internet. Responsibility berarti bertanggung jawab dengan segala postingan. Dan reasoning mengacu pada penggunaan logika dan data dalam menelusur informasi.

\section{DAFTAR PUSTAKA}

Bates, D. (2013). Are 'Digital Natives' Equipped to Conquer the Legal Landscape? Legal Information Management. Legal Information Management, 13(3), 172-178. https:/ / doi.org/10.1017/S1472669613000418

Chaves, H. Vi., Filho, O. N. M., \& Melo's, A. S. E. de. (2016). Education in Times Net Generation: How Digital Immigrants Can Teach Digital Natives?/Educação Em Tempos Net Generation: Como os Digital Immigrants Podem Ensinar os Digital Natives? HOLOS, 32(2), 347-356. https:/ / doi.org/10.15628/holos.2016.3611 
Cullen, R. (2001). Addressing the digital divide. Online Information Review. https:// doi.org/10.1108/14684520110410517

Dahl, A. J., D’Alessandro, A. M., Peltier, J. W., \& Swan, E. L. (2018). Differential effects of omni-channel touchpoints and digital behaviors on digital natives' social cause engagement. Journal of Research in Interactive Marketing, 12(3), 258- 273. https:// doi. org/ https:// remote- 1 ib. ui. ac. id: 2116 / 10 . 1108 / JRIM-04-2018-0051

Digitalcitizenship.nsw.edu.au. (2020). The 4Rs: respect, resilience, responsibility and $r$

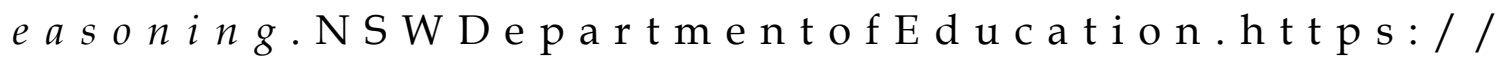
www.digitalcitizenship.nsw.edu.au/articles/the-4rs-respect-resilienceresponsibility-and-reasoning

Eisenstadt, S. N., \& Roniger, L. (1980). Patron-Client Relations as a Model of Structuring Social Exchange. Comparative Studies in Society and History, 22(1), 4277. https:/ / doi.org/10.1017/S0010417500009154

Furini, M. (2014). Users behavior in location-aware services: Digital natives versus digital immigrants. Advances in Human-Computer Interaction. https://doi.org/ $10.1155 / 2014 / 678165$

Gkioulos, V., Wangen, G., \& Katsikas, S. K. (2017). User modelling validation over the security awareness of digital natives. Future Internet, 9(3). https:/ / doi.org/ 10.3390/fi9030032

Heylighen, F. (1992). A Cognitive-systemic Reconstruction of Maslow's Theory of SelfActualization. Behavioral Science, 37(1), 39-58. https://doi.org/10.1002/ bs.3830370105

Hofer, S. S. (2018). Factors Influencing Mobile Phone Payment Processing Adoption among Digital and Non-digital Natives: A Correlation Study. In ProQuest 
Dissertations and Theses Global.

Ireton, C., \& Posetti, J. (2018). Journalism, “Fake News”, \& Disinformation. In United Nations Educational, Scientific and Cultural Organization.

Jabłońska, M. R., \& Zajdel, R. (2019). Time perspectives and online behavior of digital natives at the tertiary education level. Polish Sociological Review. https:// doi.org/10.26412/psr206.06

Kemp, S. (2019). Digital 2019: Global internet use accelerates. We Are Social \& Hootsuites.

Kesterson, K. A. (2015). A phenomenological investigation of transactional reading experiences of 12th grade digital natives in rural northeast Georgia: Print and digital texts. In ProQuest Dissertations and Theses Global.

Koh, K. (2011). Proposing a theoretical framework for digital age youth information behavior building upon radical change theory. In ProQuest Dissertations and Theses Global.

Lazorko, K. (2015). Sharing as an Aspect of Customer Behaviour of Digital Natives in Poland. Theory, Methodology, Practice, 11(2), 31-36. https://doi.org/10.18096/ tmp.2015.02.04

Lewandowski, N. M. (2019). Self-efficacy assessing digital competency: The relationship between measures of digital nativeness. In Dissertation Abstracts International Section A: Humanities and Social Sciences.

Manik, D. I. (2015). Social media consumption habits within the millennial generation: A comparison between U.S. and bangladesh.

Maslow, A. H. (1958). A Dynamic Theory of Human Motivation. In Understanding 
human motivation. https:/ / doi.org/10.1037/11305-004

McVee, M. B., Dunsmore, K., \& Gavelek, J. R. (2005). Schema theory revisited. In Review of Educational Research. https:/ / doi.org/10.3102/00346543075004531

Núñez-Gómez, P., García-Guardia, M. L., \& Hermida-Ayala, L. A. (2012). Trends in the social and interpersonal relations of young people and digital natives in the Web 2.0. Revista Latina de Comunicación Social, 67, 179-201. https://doi.org/ 10.4185/RLCS-067-952-179-201-EN

Purnell, D. L. (2017). An examination of the relationships between behavioral intention, digital nativity and the consumption of popular music. In ProQuest Dissertations \& Theses Global. Wilmington University.

Rahmawati, D., Mulyana, D., Karlinah, S., \& Hadisiwi, P. (2018). The cultural characteristics of online players in the internet cafes of jabodetabek, Indonesia. Journal of Theoretical and Applied Information Technology, 96(7), 1868-1883.

Rahmawati, D., Mulyana, D., \& Safitri, D. (2019). Knowledge Sharing Dynamics Among DOTA 2 Online Gamers at Indonesian Internet Cafes. SEARCH (Malaysia), 11(3), 41-53.

Rosenblatt, L. M. (1988). Writing and Reading:The Transactional Theory. In Technical Report No. 416.

Shih, P. H., Yang, K. C., \& Yang, C. (2018). The link between state-of-mind and individuals' willingness to adopt and continue using smartphones. Kybernetes, 47(3), 539-558. https:// doi.org/10.1108/K-12-2016-0354

Shrivastava, S. (2017). Digital Disruption is Redefining the Customer Experience: The Digital Transformation Approach of the Communications Service Providers. 
Communications Vol. 2 No. 2 Juli 2020

DOI:https://doi.org/10.21009/Communications.2.2.5

Telecom Business Review, 10(1), 41-52.

Spangler, S. C. (2015). What is the cultural experience of the digital native student today (2015)? In ProQuest Dissertations and Theses.

Stockham, M. (2016). Digital natives vs. digital immigrants at work: Evaluating computer self-efficacy as a moderator of generational differences in work values. ABI/INFORM Collection; ProQuest Dissertations \& Theses Global.

Suwana, F. (2019). Building Digital Communities. Cross-Generational and Gender Issues Paper Presented at Democratic Resilience Workshop, Queensland University of Technology.

Tandoc, E. C., Lim, Z. W., \& Ling, R. (2018). Defining “Fake News.” Digital Journalism, 6(2), 137-153.https:/ / doi.org/10.1080/21670811.2017.1360143

Tufts, D. R. (2010). Digital adults: Beyond the myth of the digital native generation gap. ProQuest Dissertations $\mathcal{E}$ Theses Global.

Wang, Q., Myers, M. D., \& Sundaram, D. (2013). Digital natives and digital immigrants: Towards a model of digital fluency. Business and Information Systems Engineering, 5(6), 409-419. https:/ / doi.org/10.1007/s12599-013-0296-y

Wolf, E. R. (1966). Kinship, friendship, and patron-client relations in complex societies. In Social Anthropology of Complex Societies (pp. 1-22). https://doi.org/ $10.4324 / 9781315017631$

Young, W. D. (2012). An examination of digital nativity, generation, and gender in online giving. In ABI/INFORM Collection; ProQuest Dissertations \& Theses Global.

Zarenejad, A. (2018). The impact of social digital behavior on digital natives' computer 
security behavior at home - A regression study. In ProQuest Dissertations $\mathcal{E}$ Theses Global.

Zimerman, M. (2012). Digital natives, searching behavior and the library. New Library World. https:/ / doi.org/10.1108/03074801211218552 